Research Papers

\title{
Origin and Availability of Large Cavities for Barrow's Goldeneye (Bucephala islandica), a Species at Risk Inhabiting the Eastern Canadian Boreal Forest
}

\section{Provenance et disponibilité de grandes cavités pour le Garrot d'Islande (Bucephala islandica), une espèce en péril de la forêt boréale de l'Est canadien}

\author{
$\underline{\text { Marie-Andrée Vaillancourt }}^{1}$, Pierre Drapeau $^{1}, \underline{\text { Michel Robert }}^{2}$, and Sylvie Gauthier $^{3}$
}

\begin{abstract}
Large secondary-nesting birds such as ducks rely on appropriate cavities for breeding. The main objective of this study was to assess the availability of large cavities and the potential of a managed boreal coniferous landscape to provide nesting trees within the breeding area of the eastern population of Barrow's Goldeneye (Bucephala islandica), a cavity-nesting species at risk in Canada. Woodpecker surveys were conducted in both conifer and mixed-wood landscapes, and cavities were sought in line transects distributed in unharvested and linear remnant stands of balsam fir (Abies balsamea) and black spruce (Picea mariana) as well as in cutblocks. No Pileated Woodpeckers (Dryocopus pileatus) were detected in the breeding area of Barrow's Goldeneye, but the species was present in the nearby lowland area in which trembling aspen (Populus tremuloides) is abundant. Only 10 trees $(0.2 \%$ of those sampled) supported cavities considered suitable for Barrow's Goldeneye in terms of dimensions and canopy openness. Most of the suitable cavities found during this study were nonexcavated apical (chimney) cavities in relatively short snags that showed advanced states of decay. A diameter-at-breast-height threshold was determined for each tree species, after which the probability of cavity occurrence was enhanced in terms of potential cavity trees for Barrow's Goldeneye. Remnant linear forest sites had lower potential tree densities than did their unharvested equivalents. Large cavities were thus a rare component in this boreal landscape, suggesting that they may be a limiting factor for this population at risk. Current even-aged forest management that mainly relies on clear-cut practices is likely to further reduce the potential of this landscape to provide trees with suitable cavities.
\end{abstract}

RÉSUMÉ. Les oiseaux de grande taille qui sont des utilisateurs secondaires de cavités, comme les canards, dépendent de cavités adéquates pour nicher. L'objectif principal de cette recherche était d'évaluer la disponibilité de grandes cavités et le potentiel d'un paysage de forêt boréale coniférienne aménagée à fournir des arbres dans lesquels le Garrot d'Islande (Bucephala islandica) de la population de l'Est, une espèce cavicole en péril au Canada, peut nicher. Des relevés de pics ont été effectués dans des paysages conifériens et mixtes, et des recherches de cavités ont été faites dans des transects situés en forêts non récoltées et en forêts résiduelles linéaires de Sapin baumier (Abies balsamea) et d'Épinette noire (Picea mariana), ainsi que dans des parterres de coupe. Aucun Grand Pic (Dryocopus pileatus) n'a été observé dans l'aire de nidification du Garrot d'Islande, mais cet excavateur primaire était présent dans les basses terres avoisinantes, où le Peuplier faux-tremble (Populus tremuloides) est abondant. Seulement 10 arbres, soit $0,2 \%$ des arbres échantillonnés, avaient des cavités jugées adéquates (bonnes dimensions et ouverture du couvert forestier suffisante) pour le Garrot d'Islande. La plupart des cavités trouvées au cours de cette recherche étaient des cavités apicales non excavées (de type cheminée) dans des chicots relativement courts

${ }^{1}$ Université du Québec à Montréal, ${ }^{2}$ Canadian Wildlife Service, ${ }^{3}$ Natural Resources Canada

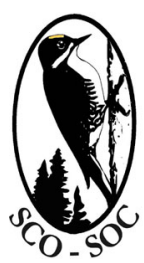

Sponsored by the Society of Canadian Ornithologists and Bird Studies Canada Parrainée par la Société des ornithologistes du Canada et Études d'oiseaux Canada

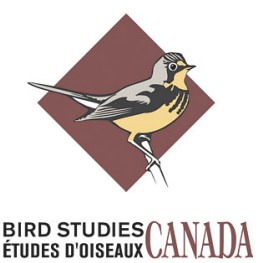


en état de décomposition avancé. Un seuil de diamètre à hauteur de poitrine, à partir duquel la probabilité d'occurrence d'une cavité augmente, a été déterminé pour chaque espèce d'arbres afin d'évaluer la disponibilité d'arbres dans lesquels la nidification du Garrot d'Islande était possible. Les forêts résiduelles linéaires avaient des densités d'arbres potentiels plus faibles que les forêts non récoltées. Les grandes cavités étaient donc des éléments rares dans ce paysage boréal, ce qui laisse croire qu'elles puissent représenter un facteur limitant pour cette population en péril. L'aménagement forestier actuel (aménagement équienne), qui repose principalement sur la pratique de coupes totales, risque vraisemblablement de diminuer encore plus le potentiel de ce paysage à fournir des arbres avec des cavités adéquates.

Key Words: Barrow's Goldeneye; cavity-nesting birds; boreal forest; remnant forests; forest management; Canada; Bucephala islandica

\section{INTRODUCTION}

Cavity-nesting species are an important and wellstudied group thanks to their potential to act as indicators of forest integrity because of their reliance on specific attributes such as decaying and dead trees during breeding (Aitken and Martin 2007). These attributes are closely associated with old-growth or naturally disturbed forests (Harmon et al. 1986, Spies et al. 1988, Sturtevant et al. 1997, Shorohova and Tetioukhin 2004) and are affected by anthropogenic disturbances such as timber harvesting (Hunter 1999, Siitonen et al. 2000, Lindenmayer and Franklin 2002, Drever et al. 2008). Studies of assemblages of cavity-nesting species have suggested that relationships between cavity-trees, excavators, and secondary cavitynesters within a forest ecosystem are structured in nest webs similar to food webs, with cavities representing the basic resource in nest webs (Martin and Eadie 1999, Martin et al. 2004). From this perspective, secondary cavity-nesting species occupy the top of the nest web and may thus be affected by changes in both forest composition and structure or by slight changes in the size of the excavator population (Imbeau et al. 2001, Monterrubio-Rico and Escalante-Pliego 2006). Conversely, they could be less dependent on excavated cavities by using nonexcavated cavities formed in decaying or dead trees if the latter were readily available (Wesolowski 2007). Studies that focused on the availability of cavities for secondary cavity-nesting birds found that the relative importance of cavity origin, i.e., excavated or nonexcavated, may vary between regions and forest ecosystems (Bai et al. 2003, 2005, Aitken and Martin 2007, Wesolowski 2007). In forests in which the availability of nonexcavated cavities is high, secondary cavity-nesting species are less reliant on excavators and show a tendency to select nonexcavated cavities (Bai et al. 2003, Remm et al. 2006, Wesolowski 2007). Nevertheless, studies published to date provide little information on the relative availability of excavated and nonexcavated cavities for larger secondary-cavity nesters such as ducks.

In North America, studies on the Wood Duck (Aix sponsa) in riparian hardwood forests have shown that suitable cavities were predominantly nonexcavated cavities located in living hardwood trees (Bellrose 1964, Prince 1968, Soulliere 1988, Lowney and Hill 1989, Robb and Bookhout 1995, Yetter et al. 1999, Roy Nielsen et al. 2007). In western Canada, several studies conducted in boreal mixed-wood forests have documented the quasiexclusive use of abandoned Pileated Woodpecker (Dryocopus pileatus) cavities by the western population of Barrow's Goldeneye (Bucephala islandica) for nesting (Bonar 2000, Eadie et al. 2000, Evans et al. 2002, Martin et al. 2004, Aitken and Martin 2007). Aitken and Martin (2007) found that Barrow's Goldeneye and Bufflehead (Bucephala albeola) used almost exclusively excavated cavities (100 and 97\%, respectively), suggesting that there might be a determinant relationship between large excavators and large secondary-nesters. Among these species, the eastern population of Barrow's Goldeneye requires particular attention because it is considered at risk by the Committee on the Status of Endangered Wildlife in Canada (COSEWIC 2008). This population numbers about 2000 pairs (Robert and Savard 2006) and breeds primarily in Quebec's eastern boreal forest (Robert et al. 2000, 2002), a region in which industrial timber harvesting is 
considered a major concern (Robert et al. 2000). Whereas there is no published information on the breeding cavities used by the eastern population of Barrow's Goldeneye, the potential of eastern boreal forests to provide trees with large cavities is likely to be altered because even-aged forest management leads to a net loss of the old forests $(>90 \mathrm{yr}$ ) that contain large live and dead trees (Gauthier et al. 2001). Hence, it becomes critical to evaluate the potential of managed eastern boreal forests to provide large cavities for Barrow's Goldeneye and other large secondary cavity-nesting species.

The main objectives of this paper were to assess (1) the availability of large cavities that can serve as nesting trees in natural forests and (2) the potential of managed forests to provide nesting trees within the breeding area of the eastern population of Barrow's Goldeneye. With regard to the availability of large cavities, we predict that those excavated by the Pileated Woodpecker would be rare because of the scarcity of this large excavator in coniferous ecosystems. In that case, large cavities available for nesting would thus primarily consist of naturally decaying hollow trees, a habitat structure that is poorly documented. Second, we predict that the potential to provide suitable cavity-trees for nesting Barrow's Goldeneyes will vary among forest types and will be reduced in managed forest stands as compared with unmanaged stands. More specifically, we ask the following questions:

1. What is the regional abundance of cavity excavators, particularly the Pileated Woodpecker, a species that directly affects the availability of nesting cavities for Barrow's Goldeneye?

2. How different is the availability of excavated and nonexcavated cavities in unharvested, remnant, and harvested forests?

3. What is the suitability of cavities with regard to Barrow's Goldeneye nesting requirements?

4. What is the potential of unharvested, remnant, and harvested forests to provide trees with cavities suitable for nesting Barrow's Goldeneye?

\section{METHODS}

\section{Study area}

The study area is located north of the Saguenay River in two Zones d'Exploitation Contrôle (ZEC) or controlled wildlife harvesting zones, Chauvin and Martin-Valin (48 $\left.33^{\prime} \mathrm{N}, 70^{\circ} 18^{\prime} \mathrm{W}\right)$. It covers $1500 \mathrm{~km}^{2}$, of which half has been recently subjected to extensive timber harvesting. The area is part of the balsam fir (Abies balsamea [L.] Mill.)-white birch (Betula papyrifera Marsh) bioclimatic zone and is characterized by steep hills with an average altitude of $640 \mathrm{~m}$ (Robitaille and Saucier 1998). Its forest cover consists of a mosaic comprising a variety of regenerating conifer and mixed-wood stands that have been harvested since the early 1980 s combined with scattered natural forest stands that have never been harvested. These unharvested mature and old (>90 yr) forest stands make up 20\% of the study area, including blocks of forest left on steep terrain and remnant forest stands in riparian strips and upland forest strips that were retained in compliance with the provincial forest management regulations of the Province of Quebec\&\#8217s Forest Act, R.S.Q., chap F-4.1.

Old forest stands are dominated by balsam fir or black spruce (Picea mariana [Mill]. B.S.P.). White spruce (Picea glauca [Moench] Voss) and white birch are also present as co-dominant species and associated with balsam fir stands (Vaillancourt et al. 2008). The first breeding record of Barrow's Goldeneye in eastern North America originated from this study area in 1998 (Robert et al. 2000). Annual surveys conducted on 60 lakes in the study area in May and June for the 1999-2003 period yielded between 24 and 43 pairs each spring (Savard and Robert 2007).

\section{Woodpecker and Barrow's Goldeneye surveys}

To determine the occurrence and distribution of primary excavators, particularly Pileated Woodpeckers, we conducted a survey using a modified version of the Breeding Bird Survey method (Sauer et al. 2001). This survey was conducted along approximately $300 \mathrm{~km}$ of the forest road network in our study area and in the adjacent southeastern area to include both the boreal coniferous landscape and the adjacent lowland boreal mixed-wood area, in which Pileated Woodpecker is more likely to occur given the importance of second-growth stands of 
trembling aspen (Populus tremuloides Michx). In all, 75 stations were located in conifer forests $(n=$ $30)$, regenerating clearcuts $(n=20)$, and mature mixed-wood stands dominated by trembling aspen $(n=25)$. All stations were at least $3 \mathrm{~km}$ apart and were visited three times between 28 May and 20 June 2005 between 05:00 and 11:00 Eastern Daylight Standard Time. Calls were played at each station using a Pignose Legendary 4 amplifier (Pignose, Las Vegas, Nevada, USA) and consisted of territory calls and drumming recordings that lasted $1 \mathrm{~min}$ followed by a listening period of $30 \mathrm{~s}$. This procedure was used for all woodpecker species known to breed at this latitude, including Downy Woodpeckers (Picoides pubescens), Black-backed Woodpeckers (P. villosus), and American Threetoed Woodpeckers ( $P$. dorsalis); Yellow-bellied Sapsuckers (Sphyrapicus varius); Northern Flickers (Coleaptes auratus); and Pileated Woodpeckers. Here, we report only the ocurrence patterns of Pileated Woodpeckers. This species was considered present at a sampling station if it was seen or heard once, within an unlimited distance radius, during any of the three visits.

We compared the distribution of Pileated Woodpeckers and Barrow's Goldeneyes using, for the duck species, data originating from a helicopter survey conducted between 28 May and 1 June 2001 (Robert et al. 2008). This survey covered 412 lakes in the study area and was designed specifically for sampling Barrow's Goldeneye pairs with regard to their breeding phenology (Robert et al. 2002). Woodpecker and Goldeneye distribution patterns were compared, using their respective occurrences in the study area, in terms of position, i.e., latitudelongitude, and altitude, which were derived from topographic maps using ARCGIS 9.1 (ESRI, Redlands, California, USA).

\section{Site selection for cavity survey}

To generate a representative sample of all forest cover types, sites were selected from both unharvested and harvested portions of the study area. Vaillancourt et al. (2008) found that the composition of forest stands is an important driver in the availability of large trees within this system, because balsam fir stands harbor more large trees than do black spruce stands. We thus applied a stratified (black spruce vs. balsam fir dominance) random procedure on digital forest cover maps (MRNFQ 2004) to select accessible stands of unharvested forests and riparian and upland remnant strips aged at least $90 \mathrm{yr}$, i.e., the age of commercial timber harvesting. Dominance in the composition of the forest cover was based on the criterion that either black spruce or balsam fir covered more than $50 \%$ of the stand's total basal area. Overall, 35 balsam fir stands and 56 black spruce stands were selected and sampled with line transects. Twentyfive clear-cut sites were also randomly selected throughout the study area. Our managed landscape consisted of the contiguous distribution of clear-cut blocks ranging from 100 to 150 ha in size that were separated by upland forest strips $60-100 \mathrm{~m}$ wide. Clearcuts were harvested between 1981 and 2000 and consisted of young regenerating stands. Although there were no specific retention guidelines in this area, clear-cut blocks comprised variable densities of remnant white birch trees or snags that had not been harvested.

\section{Cavity survey}

We surveyed cavities along line transects covering 0.2 ha $(100 \mathrm{~m} \times 20 \mathrm{~m})$ in forest stands and $0.8 \mathrm{ha}$ $(400 \mathrm{~m} \times 20 \mathrm{~m})$ in clearcuts because of lower standing tree density. Transects were located at least $100 \mathrm{~m}$ from the stand's outer limits and were randomly distributed across a sector characterized by a high density of breeding Barrow's Goldeneye pairs. All large live and dead trees with a dbh (diameter at breast height, i.e., measured $1.3 \mathrm{~m}$ above the ground) of $\geq 20 \mathrm{~cm}$ and a height of $\geq 1 \mathrm{~m}$ were measured. Species, dbh, and height were noted, and decay class was assessed. The classification used was the one described by Imbeau and Desrochers (2002), which comprises eight classes:

1. alive and healthy, $\geq 95 \%$ foliage, no sign of deterioration;

2. declining, remaining foliage between $\geq 20 \%$, and $<95 \%$, senescent tree;

3. dying, $<20 \%$, foliage remaining;

4. recently dead, hard wood, firm bark cover, $0 \%$ green foliage, and small twigs still remaining;

5. hard wood, no dead foliage, no small twigs;

6. hard wood, loose bark cover, broken top; 
7. soft decomposed wood, broken top; and

8. stump, height $\leq 2 \mathrm{~m}$.

Each tree was inspected with binoculars for cavities, and we used an infrared video camera installed at the end of a 5-m telescopic perch connected to a Sony Handycam CCD-TRV65 NTSC camera (Sony of Canada, Toronto, Ontario, Canada) to verify the presence of suspected chimney cavities. We first determined if a cavity had been excavated by a woodpecker. Nonexcavated cavities were classified as lateral or apical, i.e., chimney, cavities. Based on diameter and shape (see Stabb 1996), woodpecker cavities were classified as:

1. small (2.5-5.5 $\mathrm{cm}$ wide), created by the Downy Woodpecker;

2. medium (5.5-10 $\mathrm{cm}$ wide), created by the Hairy Woodpecker, the Black-backed Woodpecker, or the American Three-toed Woodpecker;

3. large (10-12.5 $\mathrm{cm}$ wide), created by the Northern Flicker; or

4. $>15 \mathrm{~cm}$ wide, created by the Pileated Woodpecker.

The sizes of nonexcavated lateral cavities were also classified based on these criteria. For each cavity, we measured entrance height and noted the orientation of the opening.

\section{Cavity suitability}

To find suitable nesting cavities, Goldeneyes do cavity prospecting, which consists of searching for and visiting cavities during the summer in preparation for the next breeding season (Eadie and Gauthier 1985). Considering that Barrow's Goldeneyes search for nesting cavities while flying, we assumed that canopy obstructions above a cavity would make it harder for prospecting females to detect it. Hence, we estimated the susceptibility of cavities to be detected by prospecting birds using a semi-quantitative measure of canopy closure: (1) entirely clear, (2) partially closed, and (3) entirely closed.

To assess cavity suitability for Barrow's Goldeneyes, we measured floor diameter and cavity depth in all the cavities found, as well as the entrance diameter for lateral cavities. We used a ladder to reach the highest cavities. Five cavities were too dangerous to measure because of either the advanced state of decay of the tree or its location, e.g., on a steep slope. Critical values were derived from nine nests recently discovered by the Canadian Wildlife Service in the study area (M. Robert, unpublished data) and data obtained from 41 nests found in British Columbia (M. R. Evans, unpublished data; see Evans 2003). According to these data, minimal cavity floor diameter and cavity depth were fixed at 14 and $15 \mathrm{~cm}$, respectively. We considered an entrance opening diameter larger than $10 \mathrm{~cm}$ as adequate. To be considered suitable, cavities had to meet all three criteria and be located under entirely clear or partially closed canopies.

\section{Statistical analyses}

Preliminary comparisons of the characteristics of trees containing cavities in remnant forest strips and forest stands in unharvested areas did not show significant differences. Hence, an analysis was conducted of pooled forest sites, i.e., strips and stands, by corresponding cover type. Comparisons of the densities, mean dbh values, and heights of cavity-trees were made among three cover types: clearcuts, balsam fir, and black spruce. Nonparametric Kruskal-Wallis tests were conducted because neither normality nor homoscedasticity could be assessed. We conducted pairwise comparisons using Mann-Whitney $U$ tests; to avoid type I errors, i.e., the probability of incorrectly rejecting a true null hypothesis, the statistical significance of tests was adjusted using the Bonferroni method for a significance level of $P=$ 0.017 (0.05/3 pairwise comparisons). Chi-square tests were used to compare the distribution of categorical variables including canopy closure, tree species, and decay class as well as the proportion of cavity-trees among cover types or proportion of available trees and cavity-trees. For significant relationships, we used a deviance statistic to assess which values were significantly higher or lower than expected values. The statistical significance of tests was adjusted using the Bonferroni method for a significance level of $P=0.003(0.05 / 2 * 18$ cells; Legendre and Legendre 1984). Significance patterns could then be compared among cover types.

Projections on the potential of forest cover types to provide cavity-trees for Barrow's Goldeneye were estimated with regard to tree species and dbh, two factors deemed to have an effect on the presence of 
cavities at the tree level. First, a logistic regression model of the presence or absence of a cavity was conducted for each tree species, with dbh as the independent variable. Second, for each model, we used the receiver-operating characteristic (ROC) curve to determine the optimum probability of presence, i.e., the cut-off value, of a potential cavity for which the fit between observed and predicted observations of the regression model is maximized (Manel et al. 2001). Model performance can be assessed from the area under the curve (AUC), in which a value of 1.0 indicates a perfect model and a value of 0.5 indicates no significant differences between presence and absence (DeLeo 1993). We chose the maximum accuracy to determine cut-off values, i.e., the point at which both sensitivity and specificity are maximized (DeLeo 1993). Cut-off values for each tree species were thus selected on the basis of an optimum rather than the default probability value of 0.5 that has often been used in ecological studies dealing with species occurrence data (Fielding and Bell 1997, Collingham et al. 2000, Manel et al. 2001, Guénette and Villard 2004, 2005). Third, to determine the corresponding dbh threshold values, we used the equation parameters of the regression model by isolating the $x_{\mathrm{t}}$ parameter in the following regression formula:

$$
x_{t}=\frac{\ln [1 / c-1]+\beta_{0}}{-\beta_{1}}
$$

where $\beta_{1}$ is the coefficient of the logistic regression, $\beta_{0}$ is the intercept, and $c$ is the optimum cut-off value obtained from ROC analysis.

Comparisons of different forest cover types in terms of their likelihood of providing potential cavitytrees were calculated at the stand scale as the total density of potential trees, i.e., those above the dbh threshold values obtained with ROC analyses. Here the following habitat types were considered as our independent treatments: unharvested black spruce stands and balsam fir stands, remnant black spruce and balsam fir strips, and clearcuts. In this case, it was important to determine how remnant strips differed from unharvested forest stands (controls) with regard to potential cavity-trees, because of the findings of a companion study, which showed that there were differences in the availability of large trees in stands vs. strips (Vaillancourt et al. 2008), and the increased importance of managed forests in this part of the boreal ecosystem. We thus conducted a one-way ANOVA to compare these densities among the five cover types. Our response variable, i.e., potential tree density, was square-rooted prior to the analysis to meet normality and homoscedasticity conditions. Tukey's hsd test was conducted a posteriori to assess differences between treatments.

\section{RESULTS}

\section{Occurrence and distribution of Barrow's Goldeneyes and Pileated Woodpeckers}

Pileated Woodpeckers were detected at seven (9\%) of our playback stations. Occurrences were concentrated in the mature mixed-wood stations southeast of the area used by Barrow's Goldeneyes (Fig. 1). Hence, no Pileated Woodpeckers were detected within the Barrow's Goldeneye breeding range. The shortest distance between woodpecker and Goldeneye locations was $8 \mathrm{~km}$. The mean altitude of Pileated Woodpecker occurrences was $175 \mathrm{~m}(\mathrm{SD}=89 \mathrm{~m}$; range $=10-310 \mathrm{~m})$, which is significantly lower than the one for Goldeneyes $(723 \mathrm{~m} ; \mathrm{SD}=101$, range $=490-823 \mathrm{~m}, P<0.001)$. The two species were therefore contiguous but not sympatric in our study area.

\section{Characteristics of trees supporting excavated and nonexcavated cavities}

We found 110 cavities in 86 of the 7746 trees measured in the 116 line transects sampled (Table 1). All cavities, both excavated and nonexcavated, were found on standing dead trees, hereafter called "snags." Most excavated cavities were created by medium-sized woodpeckers, with few small and large cavities and no very large excavated cavities (Fig. 2). All the excavated cavities were lateral along tree trunks. Most nonexcavated lateral cavities were large and very large (Fig. 2). Considering that sampled trees were larger than $20 \mathrm{~cm}$ dbh, all apical cavities were relatively large. Cavity densities for both types varied among treatments (Table 1). Balsam fir stands harbored three times more cavities than did black spruce stands and clearcuts. The mean dbh of cavity-trees varied among forest types and was smaller in spruce stands than in balsam fir 
Fig. 1. Pileated Woodpecker (Dryocopus pileatus) occurrence at 75 playback stations during May and June 2005 and lakes at which Barrow's Goldeneyes (Bucephalus islandica) were observed according to a helicopter survey conducted in May 2001 by the Canadian Wildlife Service over 412 lakes in the study area. This figure shows that these two species are not sympatric in the study area.



stands and clearcuts although still marginally significant, whereas the mean height of trees containing cavities did not differ significantly among forest cover types (Table 1).

Significant differences were observed among forest types in the canopy closure surrounding cavity-trees (Table 1). Cavities found in clearcuts were located under an entirely open canopy more often than expected, whereas cavities found in forest stands were more evenly distributed across canopy closure classes. Decay-class distribution in trees containing cavities did not differ significantly between treatments (Table 1). Across all forest types, cavitytrees were found mainly in highly degraded dead trees in decay classes 6 to 8 (Table 1). Both forest stands had a higher proportion of cavity-trees in decay class 7 , whereas clearcuts had a higher proportion in decay class 6 . When analyzing cavitytree occurrence with regard to the degradation status of available snags, cavity-trees occurred more often than expected in advanced decay classes, i.e., 6 to 8 (Fig. 3).

Cavities were generally found in balsam fir snags, although excavated cavities in clearcuts were mainly found in white birch snags (Table 1). However, no significant differences were found when comparing the distribution of cavity-trees with the availability of trees by species, indicating that cavities occurred in proportion to tree species availability in our study area (Table 1). 
Table 1. Characteristics of stands and trees containing cavities in balsam fir (Abies balsamea), spruce (Picea sp.), and clearcut stands in the Chauvin and Martin-Valin controlled wildlife harvesting zones, Quebec, Canada, 2004-2005. The acronym "dbh" stands for diameter at breast height. "Spruce sp." indicates snags that could be identified only with regard to genera, whereas "conifer sp." indicates snags that could not be identified at all.

\begin{tabular}{|c|c|c|c|c|}
\hline Characteristics & Balsam fir stands & Spruce stands & Clearcuts & $P$ \\
\hline $\begin{array}{l}\text { No. of living trees } \\
\text { sampled }\end{array}$ & 2532 & 2224 & 124 & \\
\hline $\begin{array}{l}\text { No. of dead trees } \\
\text { sampled }\end{array}$ & 1113 & 1188 & 565 & \\
\hline No. of cavities found & 59 & 21 & 30 & \\
\hline \multicolumn{5}{|l|}{$\begin{array}{l}\text { Cavity-tree density } \\
\text { (no./ha) })^{\dagger}\end{array}$} \\
\hline Total & $6.5( \pm 1.1)$ a & $1.7( \pm 0.5) b$ & $1.5( \pm 0.3) b$ & $<0.0001$ \\
\hline $\begin{array}{l}\text { Excavated by } \\
\text { woodpecker }\end{array}$ & $3.3( \pm 0.7) \mathrm{a}$ & $0.9( \pm 0.4) \mathrm{b}$ & $0.9( \pm 0.4) a b$ & 0.003 \\
\hline Nonexcavated & $3.2( \pm 0.7) \mathrm{a}$ & $0.8( \pm 0.2) \mathrm{b}$ & $0.7( \pm 0.2) \mathrm{ab}$ & 0.006 \\
\hline \multicolumn{5}{|l|}{$\begin{array}{l}\text { Mean cavity-tree dbh } \\
(\mathrm{cm})^{\dagger}\end{array}$} \\
\hline Total & $30.2( \pm 1.1) \mathrm{a}$ & $25.7( \pm 1.7) b$ & $30.8( \pm 1.5) \mathrm{ab}$ & 0.032 \\
\hline $\begin{array}{l}\text { Excavated by } \\
\text { woodpecker }\end{array}$ & $28.3( \pm 1.5) \mathrm{ab}$ & $24.4( \pm 2.3) \mathrm{a}$ & $33.7( \pm 1.9) b$ & 0.013 \\
\hline Nonexcavated & $32.0( \pm 1.6)$ & $26.6( \pm 2.3)$ & $27.9( \pm 2.2)$ & 0.102 \\
\hline \multicolumn{5}{|l|}{$\begin{array}{l}\text { Mean cavity-tree } \\
\text { height }(\mathrm{m})^{\dagger}\end{array}$} \\
\hline Total & $5.1( \pm 0.5)$ & $5.5( \pm 0.7)$ & $4.9( \pm 0.7)$ & 0.350 \\
\hline $\begin{array}{l}\text { Excavated by } \\
\text { woodpecker }\end{array}$ & $7.1( \pm 0.8)$ & $6.9( \pm 1.2)$ & $6.3( \pm 1.0)$ & 0.310 \\
\hline Nonexcavated & $3.2( \pm 0.4)$ & $4.4( \pm 0.6)$ & $3.4( \pm 0.7)$ & 0.328 \\
\hline $\begin{array}{l}\text { Distribution of canopy } \\
\text { closure index }(\%)^{\ddagger}\end{array}$ & & & & 0.005 \\
\hline Clear (1) & $23.7(-)$ & 35.3 & $78.6(+)$ & \\
\hline Partially closed (2) & 47.4 & $11.8(-)$ & $14.3(-)$ & \\
\hline Closed (3) & 28.9 & 52.9 & $7.1(-)$ & \\
\hline $\begin{array}{l}\text { Distribution of decay- } \\
\text { class }(\%)^{\ddagger}\end{array}$ & & & & 0.08 \\
\hline
\end{tabular}


5

6

7

8

Distribution of cavity-

tree species $(\%)^{\ddagger}$

Excavated by

woodpecker

Balsam fir

White birch (Betula

papyrifera)

White spruce (Picea

glauca)

Black spruce (Picea

mariana)

Spruce sp.

Conifer sp.

Nonexcavated

Balsam fir

White birch

White spruce

Black spruce

Spruce sp.

Conifer sp.
4.3

11.5

38.1

42.9

19.0

21.7

38.5

54.3

19.2

19.6

30.8

11.1

†Standard errors are in parentheses, a nonparametric Kruskal-Wallis test was conducted, and post-hoc pairwise comparisons were determined using Mann-Whitney $U$ tests. Different letters indicate significant differences among treatments.

¥ Chi-square tests were conducted for differences among distributions, and "+" and "-" indicate values that were significantly higher or lower than expected values. 
Fig. 2. Number of cavities found for each cavity type in the Chauvin and Martin-Valin controlled wildlife harvesting zones, Quebec, Canada. 1 = small cavities, $2=$ medium cavities, 3 = large cavities, $4=$ very large cavities, and $5=$ apical cavities. See Methods for more details on cavity size and type.

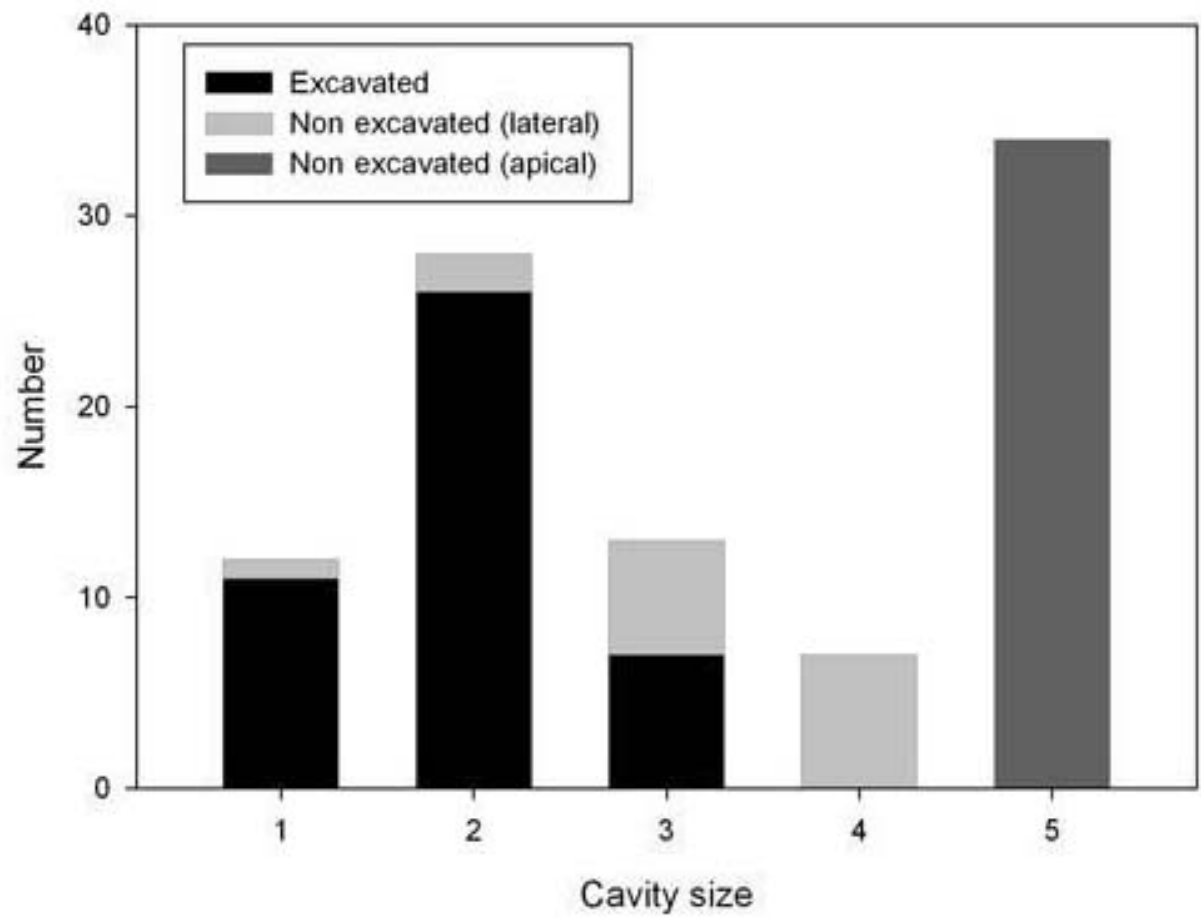

\section{Suitability of cavities for Barrow's Goldeneye}

Because no very large excavated cavities were found, further field measurements of cavities to determine their potential suitability for breeding Barrow's Goldeneyes could only be conducted on nonexcavated cavities. Among the 2866 snags measured during this study, we conducted detailed measurements on 45 trees containing 46 nonexcavated cavities. Among these, 27 cavities did not meet our suitability criteria in terms of dimensions (see Methods), whereas of the 18 (38\%) that did meet these criteria, only $10(22 \%)$ were partly visible. The characteristics of all suitable cavities, including those under closed canopy, are shown in Table 2. More than half of the visible cavities were located in clearcuts, whereas cavities considered not visible were more evenly distributed among stand types. Only one lateral cavity was suitable, with the remaining ones being apical. Most cavities $(61 \%)$ were in highly degraded balsam fir trees in decay classes 7 and 8.

\section{Availability of potential nonexcavated cavity- trees in unharvested and remnant old-growth forests and in clearcuts}

Tree dbh thresholds obtained from ROC analyses were similar among tree species (Table 3). Model accuracy for each tree species was moderate $(0.6 \leq$ AUC $\leq 0.71)$ given the low sample size of cavities but showed a trend toward cavity occurrence in larger trees. The density of trees corresponding to these thresholds, i.e., potential cavity-trees, differed among forest types $(P<0.0001 ;$ Fig. 4$)$. The density of potential cavity-trees was higher in balsam fir stands than in spruce stands and clearcuts. Finally, unharvested stands had higher numbers of potential cavity-trees than did corresponding linear stands for both balsam fir and spruce. 
Fig. 3. Proportion of available trees (filled bars) and cavity-trees (shaded bars) for each decay class in the Chauvin and Martin-Valin controlled wildlife harvesting zones, Quebec, Canada. Cavities occur more often than expected in highly degraded trees $\left(\chi^{2}=179.831 ; \mathrm{DF}=6 ; P<0.0001\right)$.

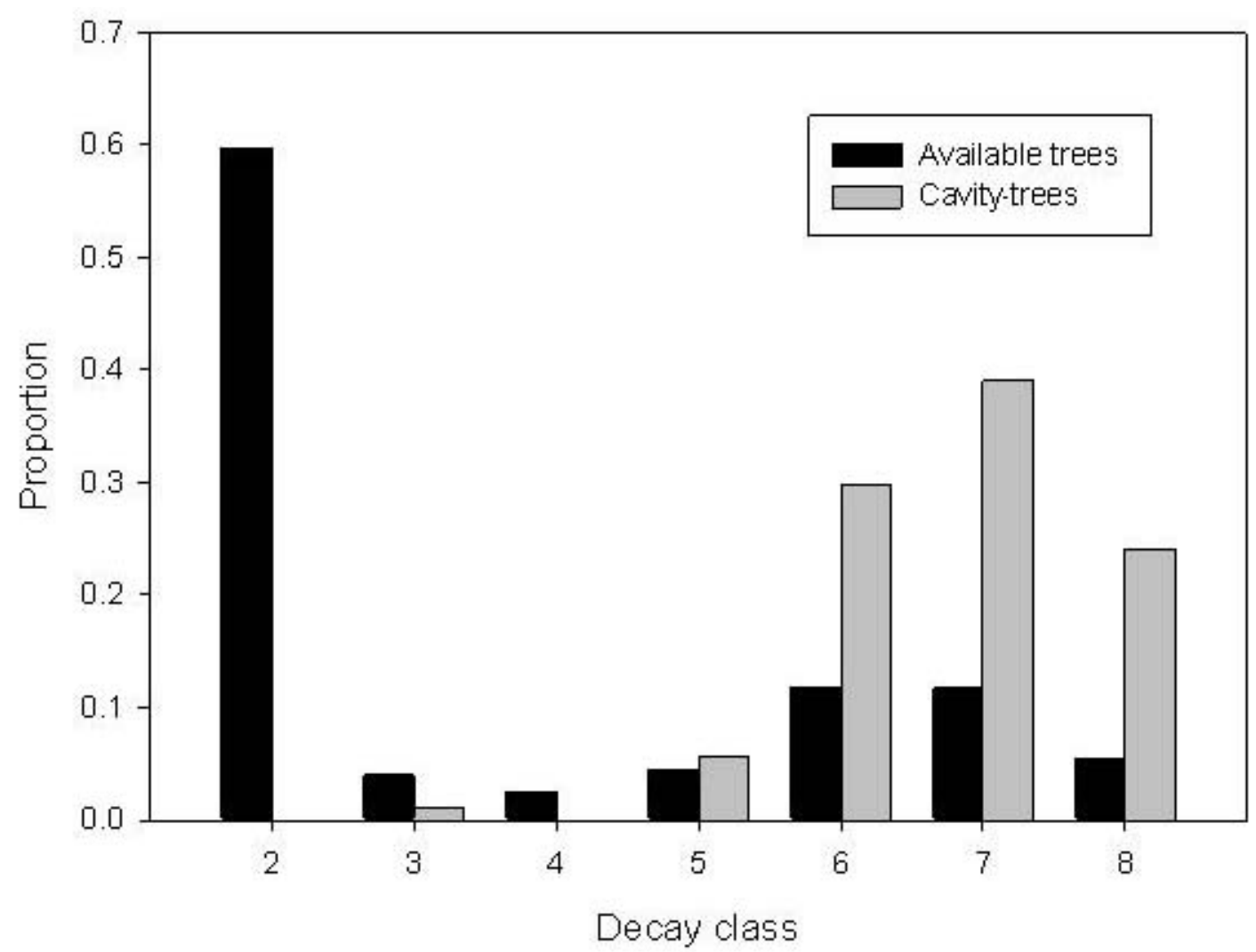

\section{DISCUSSION}

\section{Cavity availability}

The primary excavator on which a large bird species like Barrow's Goldeneye is most likely to rely is the Pileated Woodpecker. Our results clearly show that, even though this large primary excavator is present in the region, it does not occur within the areas used by Barrow's Goldeneyes for breeding. Pileated Woodpecker occurrences were concentrated along the Saguenay River in nearby lowland stands of mature boreal mixed wood that resulted from old clearcuts in which trembling aspen was abundant (MRNFQ 2004). The association of Pileated Woodpeckers with trembling aspen in mixed-wood forest is well established, and several studies have shown that they prefer to excavate nesting cavities in this tree species (e.g., Harestad and Keisker 1989. Li and Martin 1991, Martin and Eadie 1999, Martin et al. 2004, Remm et al. 2006, Gasse 2007), which has proven to be the one most likely to contain the large Pileated Woodpecker cavities used by nesting Barrow's Goldeneyes from the western population (Evans et al. 2002). The absence of this excavator in our study area is unlikely to be related to the lack of large-diameter trees $(>20 \mathrm{~cm})$, which are abundant (Vaillancourt et al. 2008). In this part of the boreal forest, naturally disturbed landscapes are characterized by long fire cycles (Gauthier et al. 2001, Bergeron et al. 2004, 2006), which provide a high proportion of old-growth coniferous forest cover that includes high densities of large-diameter trees (Aakala et al. 2007, Vaillancourt et al. 2008). However, these trees are mainly coniferous species, because deciduous species, mainly white birch, are 
Table 2. Stand type and physical characteristics of cavities considered suitable for the breeding of Barrow's Goldeneyes (Bucephala islandica) found in 43 ha of linear transects located in unharvested (17.2 ha), remnant (5.8 ha), and harvested forests (20 ha) of balsam fir (Abies balsamea) and black spruce (Picea mariana) in the Chauvin and Martin-Valin controlled wildlife harvesting zones, Quebec, Canada, 20042005; "dbh" stands for diameter at breast height. Entrance dimensions are not included in this table because only one lateral cavity was considered suitable and its entrance dimensions met the established criteria. Refer to the Methods section for details on classifying decay and canopy closure. NA means that measurements could not be taken on cavity 13, but the cavity was visually assessed.

\begin{tabular}{|c|c|c|c|c|c|c|c|c|}
\hline Stand type & $\begin{array}{l}\text { Cavity } \\
\text { type }\end{array}$ & $\begin{array}{l}\text { Tree } \\
\text { species }\end{array}$ & $\mathrm{dbh}(\mathrm{cm})$ & Decay class & $\begin{array}{l}\text { Canopy } \\
\text { closure } \\
\text { class }\end{array}$ & $\begin{array}{l}\text { Cavity } \\
\text { height } \\
(\mathrm{m})\end{array}$ & $\begin{array}{l}\text { Floordiameter } \\
\qquad(\mathrm{cm})\end{array}$ & $\begin{array}{c}\text { Cavity } \\
\text { depth } \\
(\mathrm{cm})\end{array}$ \\
\hline Balsam fir & Apical & Balsam fir & 51 & 5 & 1 & 2.0 & 36 & 99 \\
\hline Clearcut & Lateral & $\begin{array}{l}\text { White } \\
\text { birch }\end{array}$ & 51 & 6 & 1 & 2.0 & $28 \times 18$ & 79 \\
\hline Clearcut & Apical & Balsam fir & 22 & 7 & 1 & 1.7 & 18 & 51 \\
\hline Clearcut & Apical & Balsam fir & 28 & 8 & 1 & 1.3 & 18 & 69 \\
\hline Clearcut & Apical & $\begin{array}{l}\text { Conifer } \\
\text { sp. }\end{array}$ & 29 & 8 & 1 & 2.2 & 18 & 132 \\
\hline $\begin{array}{l}\text { Black } \\
\text { spruce }\end{array}$ & Apical & Spruce sp. & 32 & 8 & 1 & 3.3 & 18 & 79 \\
\hline Clearcut & Apical & Balsam fir & 30 & 8 & 1 & 1.3 & 15 & 53 \\
\hline Balsam fir & Apical & $\begin{array}{l}\text { White } \\
\text { birch }\end{array}$ & 31 & 7 & 2 & 1.8 & 23 & 43 \\
\hline Clearcut & Apical & Balsam fir & 24 & 8 & 2 & 1.8 & 15 & 66 \\
\hline $\begin{array}{l}\text { Black } \\
\text { spruce }\end{array}$ & Apical & Balsam fir & 29 & 7 & 2 & 2.1 & 15 & 53 \\
\hline Balsam fir & Apical & Balsam fir & 21 & 8 & 3 & 1.5 & 17 & 56 \\
\hline $\begin{array}{l}\text { Black } \\
\text { spruce }\end{array}$ & Apical & Balsam fir & 36 & 8 & 3 & 1.8 & 25 & 81 \\
\hline Balsam fir & Apical & Balsam fir & 31 & 8 & 3 & 1.0 & NA & NA \\
\hline Clearcut & Apical & Spruce sp. & 26 & 8 & 3 & 2.0 & 17 & 81 \\
\hline Clearcut & Apical & Balsam fir & 34 & 8 & 3 & 3.5 & 20 & 119 \\
\hline Balsam fir & Apical & Balsam fir & 36 & 7 & 3 & 1.5 & 24 & 41 \\
\hline Clearcut & Apical & Balsam fir & 20 & 8 & 3 & 1.8 & 15 & 76 \\
\hline $\begin{array}{l}\text { Black } \\
\text { spruce }\end{array}$ & Apical & $\begin{array}{l}\text { Conifer } \\
\text { sp. }\end{array}$ & 22 & 8 & 3 & 3.4 & 84 & 14 \\
\hline
\end{tabular}


Table 3. Diameter-at-breast-height (dbh) threshold values $\left(x_{\mathrm{t}}\right)$ for the occurrence of nonexcavated cavities in different tree species. $\beta 1$ and $\beta 0$ correspond to the parameter estimate and intercept of the logistic regression between dbh and occurrence of cavity. AUC is the area under the receiver-operating characteristic (ROC) curve, and $c$ is the cut-off value obtained from the ROC curves (see Methods).

\begin{tabular}{lccccc}
\hline \hline Tree species & $\beta_{1}$ & $\beta_{0}$ & AUC & $\mathrm{c}$ & $x_{\mathrm{t}}(\mathrm{cm})$ \\
\hline $\begin{array}{l}\text { Balsam fir } \\
\text { (Abies balsamea) }\end{array}$ & 0.107 & -7.34 & 0.63 & 0.0122 & 27.6 \\
$\begin{array}{l}\text { White birch } \\
\text { (Betula papyrifera) }\end{array}$ & 0.111 & -8.36 & 0.69 & 0.0069 & 30.5 \\
$\begin{array}{l}\text { Spruce sp. } \\
\text { (Picea } \text { sp.) }\end{array}$ & 0.077 & -7.96 & 0.71 & 0.0032 & 28.8 \\
\hline
\end{tabular}

less frequent (Boucher et al. 2003). The dominance of old-growth conifer stands in the eastern portion of Quebec's boreal forest (Bergeron et al. 1999, Boucher et al. 2003) may explain why the Pileated Woodpecker is a rare breeder in Quebec's North Shore region (Gauthier and Aubry 1996). Its contribution to the supply of Barrow's Goldeneye breeding cavities is, in all probability, at best marginal.

The largest excavated cavities found in our study area were created by the Northern Flicker. Although a few Barrow's Goldeneye nesting sites have been identified as enlarged flicker cavities (Palmer 1976, Bellrose 1980), these are usually considered too small for Barrow's Goldeneyes and are instead used by the smaller Bufflehead (Peterson and Gauthier 1985, Evans et al. 2002). The largest cavities we found were all nonexcavated and few in number. Although the occurrence of such cavities in conifer tree species has been documented (see Bai et al. 2003, Wesolowski 2007), their low densities in our study area may be attributed to the fact that they are less prone than hardwood species to develop cavities because of the absence of large branches, which prevents the formation of limb holes (Waters et al. 1990). Overall, this pinpoints the critical role of nonexcavated cavities for Barrow's Goldeneye breeding in Quebec's eastern boreal forest, i.e., the core breeding area of this population at risk (Robert et al. 2000, 2002). In our opinion, this study clearly suggests that the eastern population of Barrow's Goldeneyes strongly relies on nonexcavated tree cavities for nesting, which is in accordance with data relative to the few nests discovered so far (M.
Robert, unpublished data). Knowing that such cavities constitute a rare component in the eastern boreal forest ecosystem and that the Icelandic population of Barrow's Goldeneye uses groundlevel rock cavities for nesting (Einarsson 1997), we feel that there is an urgent need to gather data on the natural nesting cavities used by the eastern population.

Overall, cavity availability, quality factors such as diameter and decay class, and detectability differed significantly among stand types. Balsam fir stands offered higher cavity densities compared with spruce and clear-cut stands. In addition, balsam fir stands had a higher intermediate canopy closure, larger cavity-trees, and a higher abundance of potential cavity-trees as identified by our threshold analysis. The lower abundance of cavities in clearcuts was mainly explained by the great reduction in stem density. Consequently, tree density reduction helps to increase the degree of canopy openness around cavity-trees as well as the detection of cavities in those areas. However, this higher level of detectability in cutover areas is only temporary because it will decrease as regeneration height increases.

Although we found the highest proportion of cavities in balsam fir, they were distributed in proportion to the availability of this species in the study area. Bai et al. (2003) reported that birch (Betula platyphylla) was an important cavity-tree in conifer forests in Mongolia, and several authors found that trembling aspen was primarily selected as a host tree by most primary excavators, as well 
Fig. 4. Mean densities of potential cavity-trees with regard to stand type in unharvested stands, remnant stands, and clearcuts of balsam fir (Abies balsamea) and black spruce (Picea mariana) in the Chauvin and Martin-Valin controlled wildlife harvesting zones, Quebec, Canada. This figure shows that the availability of potential cavity-trees is significantly reduced in managed stands. Different letters indicate a significant difference between treatments at $P=0.05$ using the Tukey' hsd test. The five treatments were compared simultaneously.

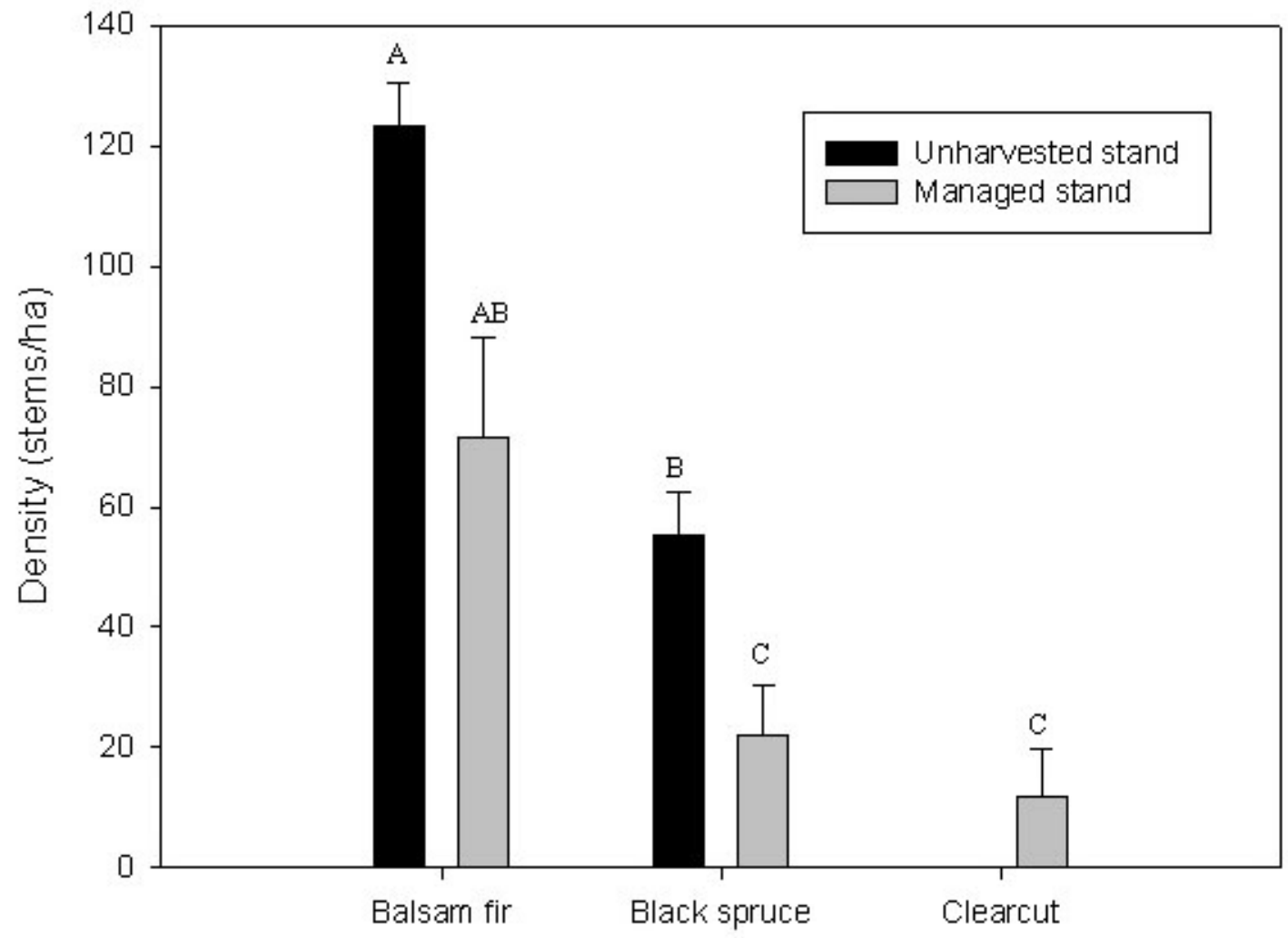

as by a large proportion of secondary users in North American mixed-wood forests (e.g., Harestad and Kesker 1989, Li and Martin 1991, Martin et al. 2004). This was not the case in our study, in which cavities in white birch occurred in proportion to its availability and trembling aspen was scarce. In other respects, all the cavities detected during this study were in dead trees, predominantly in highly degraded ones. For excavated cavities, not all of the cavities detected had been recently created, so we could not determine at which decay stage they were excavated, nor could we ignore the possibility that some old cavities may have been excavated in live trees or recently dead trees. However, the formation of nonexcavated cavities, particularly apical ones, is clearly a long process for both conifer species and white birch. The decay stage of snags may thus be a more reliable predictor of cavity occurrence than tree species in conifer boreal forests. The high density of trees in an advanced state of decay probably represents a key element for providing large nesting cavities for Barrow's Goldeneyes.

\section{Suitable cavities for Barrow's Goldeneye}

Because very little information is available on the use of natural cavities by Barrow's Goldeneyes from the eastern population, we assessed suitability based exclusively on physical constraints related to size opening and detectability. Nevertheless, cavities that fit these requirements were scarce. 
From 7746 trees sampled, including 2866 snags, only $18(0.2 \%)$, all of which were snags, contained a cavity large enough to potentially provide a nesting site for Barrow's Goldeneye. This clearly indicates that nonexcavated cavities suitable for this bird are rare in coniferous boreal forests. Furthermore, all suitable cavities were in snags in an advanced stage of degradation; this contrasts with other studies conducted on Bucephala species in North America, most of which describe nesting sites as excavated or nonexcavated cavities occurring in living or slightly decaying hardwood species (Prince 1968, Peterson and Gauthier 1985, Gauthier and Smith 1987, Evans 2003). Several studies conducted on Wood Ducks in riparian forests also reported similar descriptions for natural nesting sites (Gilmer et al. 1978, Soulliere 1988, Lowney and Hill 1989, Robb and Bookhout 1995, Yetter et al. 1999). Processes involved in the creation of cavities are not well understood and include stochastic factors that make them difficult to predict (Lindenmayer et al. 1993). We could not identify a tree species with a higher potential to support cavities, but we found that larger trees were more susceptible to natural cavities. Large decaying trees are therefore essential structural attributes of forest stands for the eastern population of Barrow's Goldeneye.

From a conservation perspective, reliance on highly degraded snags implies two important elements that could influence the availability of potential nesting sites for Barrow's Goldeneye. First, snags in an advanced state of decay may not remain standing for long, so the lifespan of nonexcavated cavities is probably short, even though this needs to be clarified with a better knowledge of the fall rates of standing dead trees. Additional studies on the recruitment rate of snags and on the formation of hollow trees during the decay process are also needed to understand the dynamics of nonexcavated cavities. Second, apical cavities occur in relatively short degraded snags in old-growth forests in which canopy closure may vary with regard to the size of the gap created by tree death, leading to variable detectability for prospecting Goldeneye females. Gaps are common in our study area because natural old-growth forest stands regulated by small-scale disturbances make up an important proportion of the land base (De Grandpré et al. 2000). For prospecting females, these canopy openings may represent essential stand features that enhance cavity detection through visual and physical access. Given that gap number and size vary according to stand composition (Pham et al.2004), more research is needed on both tree mortality and gap characteristics in relation to cavity-tree detectability and the prospecting behavior of Barrow's Goldeneye to better understand its efficiency in detecting cavity-trees in the old-growth forest cover of eastern Canada.

For the purpose of this study, we considered all cavity-trees above $1 \mathrm{~m}$ in height. So far, the small numbers of nesting cavities found in eastern Canada indicate that nesting trees are shorter than what has been reported for the western population (Evans et al. 2002), probably because the Goldeneyes in our study area use nonexcavated cavities, which are available in highly degraded trees. Evans et al. (2002) reported that Barrow's Goldeneyes selected cavities that were higher than those available, which may contribute to increasing detection and decreasing predation risks. The availability of lower cavities might be a disadvantage for Goldeneyes and expose them to higher predation risks. Incidentally, the only case of female Barrow's Goldeneye depredated in its cavity in the study area occurred in the shortest nesting tree, which was $2.1 \mathrm{~m}$ high (M. Robert, unpublished data).

In our study, most cavities defined as suitable showed parameters close to the minimal ranges identified by other studies (see Methods). Cavity size is known to influence reproductive output in cavity-nesting passerines (Karlsson and Nilsson 1977, Rendell and Robertson 1989, 1993), but it has not been investigated so far in cavity-nesting ducks. Such an assessment would refine our understanding of cavity quality. Also, many cavities were deeper than the maximal values found in other studies, which could reduce their potential for nesting females. Factors other than the size parameters used in our study can affect cavity availability and selection. For instance, Pöysä et al. (1999) found that prospecting females of Common Goldeneye (Bucephala clangula) visited nest-boxes at the shoreline and inside forests equally but preferred those located near water. To date, studies conducted on Barrow's Goldeneye have failed to identify a significant influence of contextual variables in the choice of nesting sites (Evans 2003, Savard and Robert 2007).

In addition, intraspecific interactions can affect nest site availability and quality. For example, Ålund and Andersson (2001) found that the proximity of several Common Goldeneye nests could be an advantage because nest parasitism among females may enhance female productivity. Furthermore, 
Barrow's Goldeneyes are known to be territorial (Savard 1982) and philopatric (Savard and Eadie 1989), which are behavioral traits that can influence the "true" availability of cavities within time and space. Competition with other cavity-nesting ducks or other secondary cavity-nesting species could also influence the availability of nest sites. Although no cavity-nesting species were encountered in the course of this study, potential competitors and/or predators in coniferous boreal forest include the Common Goldeneye, American Marten (Martes americana), Red Squirrel (Tamiasciurus hudsonicus), Flying Squirrel (Glaucomys sabrinus), American Kestrel (Falco sparverius), and Northern Hawk Owl (Surnia ulula). Overall, during this study we found a low density of suitable cavities for large nesting ducks such as Barrow's Goldeneye, but this estimate could be even lower if we consider other limiting factors such as context parameters, behavior constraints, and intraspecific interactions that might render habitats suboptimal.

\section{Conservation implications of large-cavity suitability for Barrow's Goldeneye in managed forests}

Our results clearly show that suitable nesting cavities are rare within the range of the eastern population of Barrow's Goldeneye. Large primary excavators are absent in this forest ecosystem, and unharvested forests harbor a very low proportion of dead stems with cavities suitable for this population at risk. Furthermore, lower densities of potential cavity-trees are found in clearcuts and remnant linear strips as compared with their natural counterparts. A lower abundance of standing dead trees in linear forest strips has been observed in other studies (Whitaker and Montevecchi 1997, Gagné 2006, Vaillancourt et al. 2008). We found highly detectable cavities in clearcuts, but the absence of recruitment in dead trees will eventually lead to a deficit in cavities and potential cavity-trees as dead decaying trees collapse. Because managed forests will make up the major part of Quebec's eastern boreal forest in the near future, timber harvesting is likely putting additional pressure on this at risk population throughout its range by reducing the density of suitable cavity-trees. Given the very low proportion of dead stems that will harbor suitable cavities for large secondary users such as ducks, high retention levels of large live and dead trees are crucially needed.
The spatial contiguousness of the breeding cavities and feeding habitats of species like Barrow's Goldeneye may allow some spatial planning in terms of choosing the areas in which to give priority to the retention of large live and dead trees. Barrow's Goldeneyes from the eastern population show a strong preference for highlands in which productive fishless lakes can be found during reproduction and the brood rearing period (Robert et al. 2008), a habitat in which large excavated cavities are naturally rare. It is therefore of crucial importance that areas near high-quality feeding habitats, i.e., fishless productive lakes in our case, be managed in a way that ensures good nesting conditions, i.e., the availability and recruitment of trees containing large cavities. To overcome a shortage of large cavities, proactive management strategies such as nest-box networks or artificially created cavities could be implemented in accessible breeding areas (but see Savard and Robert 2007). However, because of the remoteness of most of the breeding range of Barrow's Goldeneye in eastern Quebec, emphasizing management strategies that are aimed at retaining and recruiting trees that offer nest site structures for large-cavity users would probably be a more efficient conservation strategy in the long term.

Apart from setting aside permanent retention habitats within even-aged cutover areas, new management approaches should be developed for the retention and connectivity of key structural attributes, e.g., large live and dead trees, through diversified forestry practices such as partial and selection cutting that maintain the structural conditions of older forests at the landscape level (Bergeron et al. 1999, 2002, Gauthier et al. 2001). These forestry practices should be based on prior knowledge of the natural disturbance dynamics of forest ecosystems (Attiwill 1994, Angelstam 1998, Bergeron et al. 2002, DeLong 2002, Gauthier et al. 2009). Conservation targets for the supply of habitat attributes at the stand and landscape levels could include knowledge of Barrow's Goldeneye cavitytree requirements. Such a combination of ecosystem- and species-oriented management perspectives (Lindenmayer et al. 2007, Drapeau et al. 2009) could prevent the temporal and spatial interruption in the availability of large dead trees that current forest management is putting in place, and should be a prerequisite for long-term maintenance of the eastern population of Barrow's Goldeneye. 


\section{Recommendation for future studies}

Given the considerable lack of knowledge on the breeding ecology of Barrow's Goldeneye, this study found relevant baseline information on the nature of available nesting cavities in coniferous boreal forests, i.e., large, decaying, hollow trees. Future studies are crucially needed to investigate the nesting ecology of Goldeneyes using natural nesting sites and the recruitment dynamic of such structures to better predict the potential of different forest types to provide cavity-trees. Even though decay stage was found to be an important feature in Barrow's Goldeneye nesting trees, our projections did not consider this attribute because of our lack of knowledge about the transition rates between decay classes of snags (sensu Kruys et al. 2002) for the tree species under study. Efforts should also be made to increase our understanding of the factors that limit Goldeneye distribution, e.g., pond quality vs. cavity availability, and the trade-offs the species is willing to make. Finally, in the context of implementing new forest management strategies, there is a great need for more knowledge on the distribution and density of Goldeneyes in different forest types, the effects of the availability of large trees, and the influence of different management regimes within the breeding range of Barrow's Goldeneye in eastern North America. This is within the purview of adaptive management and will help refine management targets to improve the conservation of this at-risk species .

Responses to this article can be read online at: http://www.ace-eco.org/vol4/iss 1/art6/responses/

\section{Acknowledgments:}

This study was conducted with the financial support of the Sustainable Forest Management network of the Canadian Forest Service, the Environment Canada "Programme de support financier à la recherche de la Direction de la conservation de l'environnement," the Species at Risk Division of the Canadian Wildlife Service (Québec Region), the "Fonds québécois de la recherche sur la nature et les technologies (FQRNT)" with an "Actions concerties-Fonds forestier" research grant to $P$. Drapeau and an NSERC Discovery grant to $P$. Drapeau. The authors thank Laurent Dufour, Ugo Ouellet-Lapointe, and Carl Barrette for their assistance in the field, Alain Leduc for statistical advice, and Michel Melançon for producing Fig. 1. We also thank Pamela Cheers from Natural Resources Canada for editing the text.

\section{LITERATURE CITED}

Aakala, T., T. Kuuluvainen, L. De Grandpré, and S. Gauthier. 2007. Trees dying standing in the northeastern boreal old-growth forests of Quebec: spatial patterns, rates, and temporal variation. Canadian Journal of Forest Research 37:50-61.

Ålund, M., and M. Andersson. 2001. Female ducks can double their reproduction. Nature 414:600-601.

Aitken, K. E. H., and K. Martin. 2007. The importance of excavators in hole-nesting communities: availability and use of natural tree holes in old mixed forests of western Canada. Journal of Ornithology 148:S425-S434.

Angelstam, P. K. 1998. Maintaining and restoring biodiversity in European boreal forests by developing natural disturbance regimes. Journal of Vegetation Science 9:593-602.

Attwill, P. M. 1994. The disturbance of forest ecosystems: the ecological basis for conservative management. Forest Ecology and Management 63:247-300.

Bai, M. L., F. Wichmann, and M. Mühlenberg. 2003. The abundance of tree holes and their utilization by hole-nesting birds in a primeval boreal forest of Mongolia. Acta Ornithologica 38:95-102.

Bai, M. L., F. Wichmann, and M. Mühlenberg. 2005. Nest-site charactristics of hole-nesting birds in a primeval boreal forest of Mongolia. Acta Ornithologica 40:1-14.

Bellrose, F. C. 1964. Relative value of natural cavities and nesting houses for Wood Ducks. Journal of Wildlife Management 28:661-675.

Bellrose, F. C. 1980. Ducks, geese and swans of North America. Stackpole Books, Harrisburg, Pennsylvania, USA. 
Bergeron, Y., D. Cyr, C. R. Drever, M. Flannigan, S. Gauthier, D. Kneeshaw, E. Lauzon, A. Leduc, H. Le Goff, D. Lesieur, and K. Logan. 2006. Past, current, and future fire frequencies in Quebec's commercial forests: implications for the cumulative effects of harvesting and fire on age-class structure and natural disturbance-based management. Canadian Journal of Forest Research 36:2737-2744.

Bergeron, Y., M. Flannigan, S. Gauthier, A. Leduc, and P. Lefort. 2004. Past, current and future fire frequency in the Canadian boreal forest: implications for sustainable forest management. Ambio 33:356-360.

Bergeron, Y., B. Harvey, A. Leduc, and S. Gauthier. 1999. Forest management guidelines based on natural disturbance dynamics: stand- and forest-level considerations. Forestry Chronicle 75:49-54.

Bergeron, Y., A. Leduc, B. D. Harvey, and S. Gauthier. 2002. Natural fire regime: a guide for sustainable management of the Canadian boreal forest. Silva Fennica 36:81-95.

Bonar, R. L. 2000. Availability of Pileated Woodpecker cavities and use by other species. Journal of Wildlife Management 64:52-59.

Boucher, D., L. De Grandpré, and S. Gauthier. 2003. Développement d'un outil de classification de la structure des peuplements et comparaison de deux territoires de la pessière à mousses du Québec. Forestry Chronicle 79:318-328.

Collingham, Y. C., R. A. Wadsworth, B. Huntley, and P. E. Hulme. 2000. Predicting the spatial distribution of non-indigenous riparian weeds: issues of spatial scale and extent. Journal of Applied Ecology 37[Supplement 1]:13-27.

Committee on the Status of Endangered Wildlife in Canada (COSEWIC). 2008. Canadian wildlife species at risk. Available online at: www.cosewic.g c.ca/eng/sct0/rpt/rpt csar e.pdf.

De Grandpré, L., J. Morissette, and S. Gauthier. 2000. Long-term post-fire changes in the northeastern boreal forest of Quebec. Journal of Vegetation Science 11:791-800.

DeLeo, J. M. 1993. Receiver operating characteristic laboratory (ROCLAB): software for developing decision strategies that account for uncertainty. Pages 318-325 in Proceedings of the Second International Symposium on Uncertainty Modeling and Analysis. IEEE Computer Society Press, College Park, Maryland, USA.

DeLong, S. C. 2002. Using nature's template to best advantage in the Canadian boreal forest. Silva Fennica 36:401-408.

Drapeau, P., A. Leduc, and Y. Bergeron. 2009. Bridging ecosystem and multiple species approaches for setting conservation targets in managed boreal landscapes. Pages 129-160 in M.A. Villard and B.-G. Jonsson, editors. Setting conservation targets in managed forest landscapes. Cambridge University Press, Cambridge, UK.

Drever, M. C., K. E. H. Aitken, A. R. Norris, and K. Martin. 2008. Woodpeckers as reliable indicators of bird richness, forest health and harvest. Biological Conservation 141:624-634.

Eadie, J. M., and G. Gauthier. 1985. Prospecting for nest sites by cavity-nesting ducks of the genus Bucephala. The Condor 87:528-534.

Eadie, J. M., J.-P. L. Savard, and M. L. Mallory. 2000. Barrow's Goldeneye (Bucephala islandica). Birds of North America, Number 548. Academy of Natural Sciences, Philadelphia, Pennsylvania, USA, and American Ornithologists' Union, Washington, D.C., USA.

Einarsson, A. 1997. Barrow's Goldeneye (Bucephala islandica). Page 19 in W. J. M. Hagemeijer and M. J. Blair, editors. EBCC Atlas of European breeding birds: their distribution and abundance. Poyser, London, UK.

Evans, M. R. 2003. Breeding habitat selection by Barrow's Goldeneye and Bufflehead in the CaribooChilcotin region of British Columbia: nest sites, brood-rearing habitat, and competition. Dissertation. Simon Fraser University, Burnaby, British Columbia, Canada.

Evans, M. R., D. B. Lank, W. S. Boyd, and F. Cooke. 2002. A comparison of the characteristics and fate of Barrow's Goldeneye and Bufflehead nests in nest boxes and natural cavities. The Condor 104:610-619.

Fielding, A. H., and J. F. Bell. 1997. A review of 
methods for the assessment of prediction errors in conservation presence/absence models. Environmental Conservation 24:38-49.

Gagné, C. 2006. La répartition spatiale des coupes forestiéres et ses effets sur la distribution et le comportement alimentaire des oiseaux excavateurs. Thesis. Université du Québec à Montréal, Montreal, Quebec, Canada.

Gasse, A. 2007. Importance des arbres de grande taille en forêt boréale mixte, notamment du peuplier faux-tremble (Populus tremuloides) sur la distribution des oiseaux cavicoles ainsi que sur l'alimentation du Grand Pic (Dryocopus pileatus). Thesis. Université du Québec à Montréal, Montréal, Québec, Canada.

Gauthier, J., and Y. Aubry. 1996. The breeding birds of Quebec. Association québecoise des groupes d'ornithologues, Province of Quebec Society for the Protection of Birds, and Canadian Wildlife Service, Montreal, Quebec, Canada.

Gauthier, G., and J. N. M. Smith. 1987. Territorial behaviour, nest-site availability, and breeding density in Buffleheads. Journal of Animal Ecology 56:171-184.

Gauthier, S., A. Leduc, B. Harvey, Y. Bergeron, and P. Drapeau. 2001. Les perturbations naturelles et la diversité écosystémique. Naturaliste canadien 125:10-17.

Gauthier, S., M.-A. Vaillancourt, A. Leduc, L. De Grandpré, D. Kneeshaw, H. Morin, P. Drapeau, and Y. Bergeron. 2009. Ecosystem management in the borealforest. Presses de l'Université du Québec, Quebec City, Canada.

Gilmer, D. S., I. J. Ball, L. M. Cowardin, J. E. Mathisen, and J. H. Riechmann. 1978. Natural cavities used by Wood Ducks in north-central Minnesota. Journal of Wildlife Management 42:288-298.

Guénette, J.-S., and M.-A. Villard. 2004. Do empirical thresholds truly reflect species tolerance to habitat alteration? Ecological Bulletin 51:163-171.

Guénette, J.-S., and M.-A.Villard. 2005. Thresholds in forest bird response to habitat alteration as quantitative targets for conservation. Conservation Biology 19:1168-1180.
Harmon, M. E., J. F. Franklin, F. J. Swanson, P. Sollins, S. V. Gregory, J. D. Lattin, N. H. Anderson, S. P. Cline, N. G. Aumen, J. R. Sedell, G. W. Lienkaemper, K. Cromack Jr., and K. W. Cummins. 1986. Ecology of coarse woody debris in temperate ecosystems. Advances in Ecological Research 15:133-302.

Harestad, A. S., and D. G. Keisker. 1989. Nest tree use by primary cavity-nesting birds in south central British Columbia. Canadian Journal of Zoology 67:1067-1073.

Hunter, M. L., Jr., editor. 1999. Maintaining biodiversity in forest ecosystems. Cambridge University Press, Cambridge, UK.

Imbeau, L., and A. Desrochers. 2002. Foraging ecology and use of drumming trees by Three-toed Woodpeckers. Journal of Wildlife Management 66:222-231.

Imbeau, L., M. Mökköen, and A. Desrochers. 2001. Long-term effects of forestry on birds of the eastern Canadian boreal forests: a comparison with Fennoscandia. Conservation Biology 15:1151-1162.

Karlsson, J., and S. G. Nilsson. 1977. The influence of nest-box area on clutch size in some hole-nesting passerines. Ibis 119:207-211.

Kruys, N., B. G. Jonsson, and G. Stahl. 2002. A stage-based matrix model for decay-class dynamics of woody debris. Ecological Applications 12:773-781.

Legendre, L., and P. Legendre. 1984. Écologie numérique. Tome 2: La structure des données écologiques. Presses de l'Université du Québec, Quebec City, Quebec, Canada.

Li, P., and T.E. Martin. 1991. Nest-site selection and nesting success of cavity-nesting birds in high elevation forest drainages. The Auk 108:405-418.

Lindenmayer, D. B., R. B. Cunningham, C. F. Donnelly, M. T. Tanton, and H. A. Nix. 1993. The abundance and development of cavities in Eucalyptus trees: a case study in the montane forests of Victoria, southeastern Australia. Forest Ecology and Management 60:77-104.

Lindenmayer, D. B., J. Fischer, A. Felton, R. Montague-Drake, A. D. Manning, D. Simberloff, K. Youngentob, D. Saunders, D. Wilson, A. M. 
Felton, C. Blackmore, A. Lowe, S. Bond, N. Munro, and C. P. Elliot. 2007. The complementarity of single-species and ecosystemoriented research in conservation research. Oikos 116:1220-1226.

Lindenmayer, D. B., and J. F. Franklin. 2002. Conserving forest biodiversity: a comprehensive multiscaled approach. Island Press, Washington, D. C., USA.

Lowney, M. S., and E. P. Hill. 1989. Wood Duck nest sites in bottomland hardwood forests of Mississippi. Journal of Wildlife Management 53:378-382.

Manel, S., H. C. Williams, and S. J. Ormerod. 2001. Evaluating presence-absence models in ecology: the need to account for prevalence. Journal of Applied Ecology 38:921-931.

Martin, K., K. E. H. Aitken, and K. L. Wiebe. 2004. Nest sites and nest webs for cavity-nesting communities in interior British Columbia, Canada: nest characteristics and niche partitioning. The Condor 106:5-19.

Martin, K., and J. M. Eadie. 1999. Nest webs: a community-wide approach to the management and conservation of cavity-nesting forest birds. Forest Ecology and Management 115:243-257.

Ministère des Ressources naturelles et de la Faune du Québec (MRNFQ). 2004. Digitized forest maps 1:20000 (22C5, 22D8, 22D9, 22D16). MRNFQ, Direction des inventaires forestiers, Quebec City, Quebec, Canada.

Monterrubio-Rico, T. C., and P. EscalantePliego. 2006. Richness, distribution and conservation status of cavity nesting birds in Mexico. Biological Conservation 128:67-78.

Palmer, R. S. 1976. Handbook of North American birds. Volume 3: Waterfowl. Yale University Press, New Haven, Connecticut, USA.

Peterson, B., and G. Gauthier. 1985. Nest site use by cavity-nesting birds of the Cariboo Parkland, British Columbia. Wilson Bulletin 97:319-331.

Pham, A. T., L. De Grandpré, S. Gauthier, and Y. Bergeron. 2004. Gap dynamics and replacement patterns in gaps of the northeastern boreal forest of
Quebec. Canadian Journal of Forest Research 34:353-364.

Pöysä, H., M. Milonoff, V. Ruusila, and J. Virtanen. 1999. Nest-site selection in relation to habitat edge: experiments in the Common Goldeneye. Journal of Avian Biology 30:79-84.

Prince, H. H. 1968. Nest sites used by Wood Ducks and Common Goldeneyes in New Brunswick. Journal of Wildlife Management 32:489-500.

Remm, J., A. Lohmus, and K. Remm. 2006. Tree cavities in riverine forests: What determines their occurrence and use by hole-nesting passerines? Forest Ecology and Management 221:267-277.

Rendell, W. B., and R. J. Robertson. 1989. Nestsite characteristics, reproductive success and cavity availability for tree swallows breeding in natural cavities. The Condor 91:875-885.

Rendell, W. B., and R. J. Robertson. 1993. Cavity size, clutch-size and the breeding ecology of Tree Swallows Tachycineta bicolor. Ibis 135:305-310.

Robb, J. R., and T. A. Bookhout. 1995. Factors influencing Wood Duck use of natural cavities. Journal of Wildlife Management 59:372-383.

Robert, M., R. Benoit, and J.-P. L. Savard. 2002. Relationship among breeding, molting, and wintering areas of male Barrow's Goldeneyes (Bucephala islandica) in eastern North America. The Auk 119:676-684.

Robert, M., D. Bordage, J.-P. L. Savard, G. Fitzgerald, and F. Morneau. 2000. The breeding range of the Barrow's Goldeneye in eastern North America. Wilson Bulletin 112:1-7.

Robert, M., B. Drolet, and J.-P. L. Savard. 2008. Habitat features associated with Barrow's Goldeneye breeding in eastern Canada. Wilson Journal of Ornithology 120: 320-330.

Robert, M., and J.-P. L. Savard. 2006. The St. Lawrence River Estuary and Gulf: a stronghold for Barrow's Goldeneyes wintering in eastern North America. Waterbirds 29:437-450.

Robitaille, A., and J.-P. Saucier. 1998. Paysages régionaux du Québec méridional. Publications du Québec, Sainte-Foy, Quebec, Canada. 
Roy Nielsen, C. L., R. J. Gates, and E. H. Zwicker. 2007. Projected availability of natural cavities for Wood Ducks in southern Illinois. Journal of Wildlife Management 71:875-883.

Sauer, J. R., J. E. Hines, and J. Fallon. 2001. The North American breeding bird survey, results and analysis 1966-2007. Version 5.15.2008. Patuxent Wildlife Research Center, Laurel, Maryland.

Savard, J.-P. L. 1988. Use of nest boxes by Barrow's Goldeneyes: nesting success and effect on the breeding population. Wildlife Society Bulletin 16:125-132.

Savard, J.-P.L., and J. M. Eadie. 1989. Survival and breeding philopatry in Barrow's and Common Goldeneyes. The Condor 91:198-203.

Savard J.-P. L., and M. Robert. 2007. Use of nest boxes by Goldeneyes in eastern North America. Wilson Journal of Ornithology 119:28-34.

Siitonen, J., P. Martikainen, P. Punttila, and J. Rauh. 2000. Coarse woody debris and stand characteristics in mature managed and old-growth boreal mesic forests in southern Finland. Forest Ecology and Management 128:211-225.

Shorohova, E., and S. Tetioukhin. 2004. Natural disturbances and the amount of large trees, deciduous trees and coarse woody debris in the forests of Novgorod region, Russia. Ecological Bulletin 51:137-147.

Soulliere, G. J. 1988. Density of suitable Wood Duck nest cavities in a northern hardwood forest. Journal of Wildlife Management 52:86-89.

Spies, T. A., J. F. Franklin, and T. B. Thomas. 1988. Coarse woody debris in Douglas-fir forests of western Oregon and Washington. Ecology 69:1689-1702.

Stabb, M. M. 1996. Ontario's old growth: a learner's handbook. Canadian Nature Federation, Ottawa, Ontario, Canada.

Sturtevant, B. R., J. A. Bissonnette, J. N. Long, and D. W. Roberts. 1997. Coarse woody debris as a function of age, stand structure, and disturbance in boreal Newfoundland. Ecological Applications 7:702-712.
Vaillancourt, M.-A., P. Drapeau, S. Gauthier, and M. Robert. 2008. Availability of standing trees for large cavity-nesting birds in the eastern boreal forest of Quebec, Canada. Forest Ecology and Management 255:2272-2285.

Waters, J. R., B. R. Noon, and J. Verner. 1990. Lack of nest site limitation in a cavity-nesting bird community. Journal of Wildlife Management 54:239-245.

Wesolowski, T. 2007. Lessons from long-term holenester studies in a primeval temperate forest. Journal of Ornithology 148:S395-S405.

Whitaker, D. M., and W. A. Montevecchi. 1997. Breeding bird assemblages associated with riparian, interior forest, and nonriparian edge habitats in a balsam fir ecosystem. Canadian Journal of Forest Research 27:1159-1167.

Yetter, A. P., S. P. Havera, and C. S. Hine. 1999. Natural-cavity use by nesting Wood Ducks in Illinois. Journal of Wildlife Management 63:630-638. 